\title{
Assessments of Covid 19's Consequences on Business Activities the Case of East Wollega Zone -Oromia Regional State: The Current Status and Future Prospective
}

\author{
Tesfaye Eresso Gofe (Assistant Professor) \\ Department of Accounting and Finance, College of Business and Economics \\ Wollega University; Ethiopia
}

\begin{abstract}
The unexpected economic disturbance caused by Covid-19 is affecting all movements hasunexpected consequences because it created restriction in transaction and day to day activities in almost every area of human activities. The economic agony turns out to be severe as people were enforced to stay at home, and the severity was felt in various sectors of the economy with travel prohibitions affecting each and every activity of the business men and people in generalEthiopia declared state of emergency on April 8, 2020 for the next five months to get control over the virus. The state of emergency has imposed different restrictions and measures on people activities and travels. Transportation services in almost all areas are enforced to reduce the number of passengers by half. This travel ban slowdowns the economic and social interaction among people which may will result in dramatic liquidity crisis followed by economic depression. This is the current consequence of Covid-19 outbreak. In order to achieve the stated objective the descriptive research design was employed.Many people and families have suffered and will suffer from the unexpected losses around the world. It will have profound consequences on the world's business operations, social, political environments and on its economy in general. Particularly, in addition to the political instability, the Covid 19 pandemic severely affects Wollega zones of Oromia.Because of the current consequences the business operations and the daily activities of the society were diminishing. The zone official hasto adjust between the necessity to keep the business transactions working and the need to keep the populations from this current pandemic. Hence, the zone officials or any concerned body should review their activities towards protecting the Covid 19 pandemic to create a favorable situation to continue movements of significant transactions. Keywords: Covid 19, Consequences, Business activities and Economic
\end{abstract}

DOI: $10.7176 / \mathrm{JMCR} / 71-03$

Publication date:September $30^{\text {th }} 2020$

\section{Introduction}

The globe has always witnessed pandemics, plagues and influenza epidemics from ancient times till present, which negatively impacted a great part of the world on both the economic and social levels (Hasan ElMousawi\&HasanKanso, 2020). Similarly, the Covid-19 is another recent phenomena that seriously affecting the life and economic activities of the globe. After the first infections in Wuhan city of China at the end of 2019, the corona virus disease (COVID -19) has continued to spread across the world (African Union, 2020). Accordingly the World Health Organization (WHO) finally declared the Covid-19 outbreak as a global pandemic on 11 March 2020, lives have been upended and economic activities disrupted around the world. As of today, according to world health organization (WHO) report update: July29, 2020, the spread of the virus reached (confirmed cases) almost around 16,797,288 with 661,724 death in the world and around 15,810confirmed cases with 253 deathsin Ethiopian context.

An action taken in response to the spread of Covid-19 have resulted in large scale disturbance to business transactions, with more unpredictablematerial prices and currency conversation rates, and anevidentweakening in interest rates in the mainstream of economies around the globe. The globe is facing the closure of each business activities and stay at home principle by quitting different trading directions that can significantly which will eventually impact the world economy. Different literature evidences revealed that the Covid-19 had significant consequences on the financial system that directly affects the overall economy of the nation. The Covid which has affected the world in general and African economy in particular has also affected the Ethiopianeconomy through unexpected consequences to Ethiopian towns/cities. Almost all, Ethiopiancities/towns have taken bold quarantine and lockdown measures to control the spread of Covid- 19 which comes as a cost such as a collapse of health system, education, business transactions, economic crisis or economic activities.

Similarly, a knowledge from preceding crises, particularly from the Ebola virus disease outbreak in West Africa in 2014, has indicated the significant impact of movement restrictions and disease containment efforts on food production and access, and the importance of maintaining and up scaling humanitarian food security interventions for the most vulnerable populations, alongside the health sector's efforts to prevent disease spread(www.fao.org.)

Again, according to the FAO of the UN Within the framework of the UN global Covid-19 humanitarian 
response plan, FAO has reviewed its ongoing humanitarian programming and analyzed the potential consequences of the virus so as to ensure sustained support to the most susceptible and anticipatory actions to address the secondary consequences of the virus.

According to El-Erian, 2020 the sudden economic disruption caused by Covid-19 is not only destructive but also has spillover implications because it created demand and supply shocks in almost every area of human endeavor. The economic agony became severe as people were enforced to stay at home, and the severity was felt in different sectors of the economy with travel prohibitions affecting each and every activity of the people in general. The spread of the virus encouraged social distancing which led to the shutdown of financial institutions, and business activities. The degree at which the virus was spreading, and the restricted actions taken to control the pandemic make higher uncertainty about how bad the situation could get, led to danger in consumption and investment among consumers, and investors. Ethiopia also declared state of emergency on April 8, 2020 for the next five months to get control over the virus. The state of emergency has imposed different restrictions and measures on people activities and travels. The transportation services in all areas are enforced to reduce the number of travelers by half. These travel prohibition slowdowns the economic and social interaction among people which may will result in dramatic liquidity crisis followed by economic depression. This is the current consequence of Covid-19 outbreak.

This is the present expectation regarding to the virus impacts on economic and social scenarios. However, there is no clear cut about the current and future consequences of the virus on business activities and economic development. For instance, we are not quite sure about the consequences of Covid-19 on public revenues, private income, taxation, trade, inflation, investment, employment, remittance, hotel services, etc. Even less likely this pandemic could bring us good opportunity. The culture of helping each other, for example, is incredible at the time of the pandemic than before its outbreak. Thus, we are exercising magnificent humanitarian aid and good business ethic during this pandemic than ever. This might be the positive consequence of Covid-19. But still we are not sure whether the pandemic is with extreme bad or good consequences from economic perspectives.

In Ethiopian context, after the entrance of corona virus in 13 March 2020 many attentions are given to it how to defend the spread of the virus by the government and other concerned bodies. Hence, several industries and institutions responded to the disease and a number of business activities were affected from the Covid-19 shock. Apart from its health problem, an extensive increase of the disease and measures taken to control the spread in the poorer and food insecure countries could take a heavier toll on the economy and cause for economic slowdown. Every business transactions in normal economic operations are performed based on the principle of giving and receiving. A transaction requires the interaction between buyer and seller, and it occurs in the event of trading goods and services in standardized or un-standardized market. To say it a transaction- particularly business transaction- the value of given one and received instead shall be measured in monetary value. This means the value of money paid by the demander shall match the value of goods or services being received in the dealing of giving and receiving.

However, this concept does not work in the absence of dealing made between buyer and seller since the interaction is either ceased or restricted by the current infectious various Covid-19. Of course, the impacts of Covid-19 are not limited only to the financial transaction made between buyer and seller at a market place. Its consequences possibly go to economic, social and political affairs.

Our country Ethiopia is not exceptional to these consequences. Ethiopia has begun observing the consequences of the pandemic since the declaration of state of emergency on April 8, 2020. The country is under high tension due to the multidimensional hit from Covid-19.

The report issued by Deloitte on May 2020 states that Tourism and travel contributes about $2.2 \mathrm{~m}$ jobs $(8.3 \%$ of total employment). Most ofthese jobs are now at danger, with the EthiopiaAirlines already losing USD 550m between January and mid April 2020. The flower sector was estimated to generate USD 400m in 2020. Ethiopia's exports have however declined and the sector's loss is estimated at USD $110 \mathrm{~m}$ in quarter one of 2020 with over 50,000 jobs at risk.

Similarly, as it is reported in Addis fortuneabout 1.4 million jobs in the manufacturing, construction and services sectors will be threatened by the economic consequences of the Covid-19, according to a preliminary assessment done by the Jobs Creation Commission. (Addis Fortune,April 2020).

In addition, the Ethiopian's real GDP growth in 2019 was $9.0 \%$ and was forecasted to be $6.2 \%$ in 2020 preCovid-19. This forecast has now been revised downwards to $3.2 \%$ in 2020 . Regarding to job losses, significant job losses- Ethiopia's Job Creation Commission has estimated between 700,000-2 million jobs are likely to be lost in 2020 depending on the severity of the virus on Ethiopia's economy (Deloitte, 2020).

Unfortunately, the great hits of Covid-19 on economic, social and political aspects are not limited only to the present situation. The consequences of Covid - 19 may continue to appear in the future. So, assessing the current and future consequences of Covid - 19 pandemic from economic in general and transaction perspective in particular is essential. Thus, the general objective of this study is to assess the Covid $19 \mathrm{~s}$ consequences on business activities of East Wollega zone. Specifically, the study was conducted to analyze the consequences of Covid-19 
on business transactions: To identify how the Covid 19 lockdown affects the revenue of the respondents ; To describe how the coronavirus shutdown affects the business transactions of the respondents; To assess the current consequences of the Covid 19 on the day to day activities of the respondents; To discuss how the Covid 19 shutdown affects the economy of the respondents in general, and To describe the bad economic scenarios or good opportunities of Covid-19.

The assessment was conducted to resolve the following inquiries related to the consequences of Covid-19 on transaction scenarios of East Wollega zone, Oromia. Does the Covid 19 shutdown affect your revenue?; How the coronavirus shutdown affects the business transactions?; What are the current consequences of the Covid 19 on your day to day activities? ; How the Covid 19 shutdown affects you economy in general?; and Is Covid-19 come with only bad economic scenarios or good opportunities?

\section{Literature Review}

This section discusses the literaturesconcerning Covid 19 in general and the consequences of Covid 19 on the business operations and the daily activities of the community which in turn affects the business transactions and the economy of the globe.

According to the report of FAO of the UN the novel coronavirus (Covid-19) is a respiratory illness caused by a virus that was first identified at the end of 2019. As of early April 2020, WHO was reporting a continued steep rise in the number of cases and deaths worldwide, with the pandemic spreading to at least 240 countries and territories (FAO of the UN, April 2020).

In the same sense Deloitte also reports as the Covid-19 pandemic is currently causing significant adverse impact on the global economy. Governments around the world are implementing various fiscal measures to mitigate the adverse effect and provide relief for businesses and households(Deloitte on May 2020).

Although the consequences of Covid-19 on short- term and long-term business transactions and food security is problematic to forecast, some risk factors can be identified and lessons from previous pandemics such as Ebola virus disease in West Africa in 2014 or world crises such as food prices crisis of 2008 indicate that effects on food security could be rapid and of dramatic proportions.

Recent OECD data on the economic consequences of the crisis and related containment measures indicate that "the overall direct initial hit to the level of GDP is typically between $20-25 \%$ in many major advanced economies"(OECD,2020). Complete or partial shutdowns are impacting sectors in different ways; affecting to varying degrees their ability to operate, the demand for their products or services, and their balance sheets. According to a survey by the Responsible Business Alliance, as a consequence of the COVID-19 crisis, 50\% of their members' and their member's supplier factories are not functioning at full capacity, 15\% of all factories are below $50 \%$ production, and $8 \%$ of factories have fewer than $10 \%$ of their employees back to work.

According to A. Edgecliffe-Johnson,the Covid-19 crises are causing financial distress and liquidity problems for many companies as a result of the reduction or cancellation of business. This in turn impacts workers, whose income and livelihood are at risk. While some companies have been able to shield their workforce from such impacts and are choosing to keep and pay employees during the suspension of their activities, 8 many companies have had to lay off workers or reduce their working hours (A. Edgecliffe-Johnson March 2020).

In addition to the impacts of COVID-19 on companies' own operations, businesses have also faced significant disruptions in their supply chains (Sourcemap, 2020). In a survey focused on business and supply chain impacts, the Institute for Supply Management found that more than $80 \%$ of companies believe that their organization will experience some impact because of Covid-19 related disruptions(ISM,2020).

The supply chain disturbances,movement restrictions, and lockdowns have had wide consequences. Many businesses reduced their activities or temporarily closed operation. Additionally, financial transactions from different countries to Ethiopia are volatile as investors are concerned that the virus is creating a world economic and financial crisis in ways not seen since the global financial crisis. The Consequences of the Covid-19 pandemic on the economic activities in general and flow of businesses, financial transactions in particular will depend on how much further the virus will spread across the globe and its consequence on economic activity; fiscal and monetary policy responses to the shock, and regulatory measures to avoid from possible banking system fragility.

\section{Methodology of the study}

The descriptive research design was employed.In order to achieve the study objectives, data were obtained from both primary and secondary sources. . Because of the nature of Covid 19 from the nineteen (19) woreda's of east Wollega zone of Oromia, six woreda's (Nekemte, Diga, Guto Gida, Arjo Awuraja, Sibu sire and Gida Ayana) were purposively selected for observation and interview. The primary data was collected through direct observation and interview with key formants in sampled areas for the study purpose. The secondary data was obtained from documents and reports of key offices of the town municipality established to fight against Covid19. For interview purposes 107 respondents were purposively selected from the sixth woreda's based on their sizes. To achieve the objective the six woreda's were observed. The interviews were made with shops, hotels, cafeterias, 
cafeterias and restaurants from the selected six woreda's. For interview purpose the following respondents were selected and interviewed.

\begin{tabular}{|l|l|l|l|l|l|}
\hline Woreda's & Shops & Hotels & Cafeterias & Cafeterias and restaurants & Total \\
\hline Nekemte & 10 & 10 & 8 & 4 & 32 \\
\hline Diga & 5 & 5 & 3 & 2 & 15 \\
\hline GutoGida & 5 & 5 & 3 & 2 & 15 \\
\hline ArjoAwuraja & 5 & 5 & 3 & 2 & 15 \\
\hline Sibu sire & 5 & 5 & 3 & 2 & 15 \\
\hline GidaAyana & 5 & 5 & 3 & 2 & 15 \\
\hline Total & 35 & 35 & 23 & 14 & 107 \\
\hline
\end{tabular}

Source: Interview 2020

In addition to physical examination and observation in each sampled areas, existing documents and reports were reviewed.

\section{Discussions}

This section discusses the key findings of the study. The study is designed to answer the general questions such as Does the coronavirus shutdown affect the revenue of the respondents?, How the coronavirus shutdown affects the business transactions? And what are the current consequences of the Covid 19 on your day to day activities?

Based on the interviews on the key informants and the observations made within the woreda's the following key issues were observed and discussed.

Regarding to the day to day transactions of the community, Within the Wollega zones of Oromia, Ethiopia, even before the outbreak of Covid 19, the business activities including investments already highly affected because of the political instability of the country, resulted decrease in movements that affects day to day activities of the community in which the life of the community severely affected. Thus, the Covid 19 pandemic and the political uncertainty producetension to the society which in turn reduces the flow of business activity in particular. The interview result reveals that theCovid 19 outbreak decreasesthe transactions, the movement of the society, the flow of activities which in turn reduces the revenue and economic activities of the respondents of the zone.It is difficult to quantify by how much the revenue amounts of the respondents decreases because most of the shops, hotels and almost all of the cafeterias and cafeterias and restaurants have no records that show the amount.

Regarding to the physical observation the Covid 19 outbreak reduces the movement of the individuals in the town and this leads to the down turn of the transactions in the woreda.

In addition to the activities in the town, the respondents has a fear of survival due to the political instability which focuses particularly on Wollega zones which in turn again affects agricultural productivity of the rural of the woreda. The finding of the study is similar to the Asian policy brief report. According to ASEAN policy brief April 2020, In ASEAN, the pandemic has so far brought immediate disruptions in economic activities across the region, as evident in the decline in tourism flows, disruption in air travels, and weakening in consumer and business confidence, as several countries imposed lockdowns, community quarantines, stay-at-home orders, temporary business closures, and travel restrictions or prohibitions to contain the virus.

Similarly the pandemic and the political stability has so far brought immediate disruptions in business transactions and affecting the life of the society across the Wollega zones. In addition the agricultural related activities including coffee were declines, weakens the activities because of the imposed lock downs and fear of insecurity within the community.

According to the African Union, the global prices for key food related commodities, such as rice and wheat, can also impact African countries. Several African countries are net importers for these products. If the Covid-19 outbreak were to last until end of 2020 or beyond, then the question would be how the prices of these products will evolve.Several countries and economic regions have taken economic and financial measures to contain the Covid-19while also providing financial support to their economic activities(African Union, April 20).

Though the lockdown reduces the business activities and increases the price of food related items and nonfood related items in the sampled area, for instances in Nekemte town because of the Covid 19 pandemic and the political instability the price of the food related items increases at alarming rate. One kilo onion is increased from 10 birr to 50 Birr per kilo; One kg tomato is increased to $\mathrm{Br} 30$, on average One kg teff is increased from $\mathrm{Br} 26$ to $\mathrm{Br} 44$ per $\mathrm{Kg}$ etc. Again the prices of rice, pasta, macron, and similar food related items are increasing. The price increase in this food related items and the political mess highly affecting the community of the sampled area.

It is not only the give and take transactions that are currently affected by the Covid 19 but also the economic, the socio economic, even the daily income of the community also severely affected (Africa Union, 2020). 


\section{Conclusion}

The current Covid-19 pandemic has seriously affecting the world and almost over 16.5 million of confirmed cases and 661,724 thousands of deaths recorded globally. The world economy is on the ageof globally declining and it may be more serious than the global financial crisis in 2008/09. Therefore, there is a need to take extra measures to make less severe the consequences of Covid-19 pandemic.

Many people and families have suffered and will suffer from the unexpected losses around the world. It will have a profound impact on the world's business operations, social, political environments and on its economy in general. Particularly, in addition to the political instability, the Covid 19 pandemic severely affects Wollega zones of Oromia.

Because of the current consequences the business operations and the daily activities of the society were diminishing.

The Covid-19 has also a clear supply effects: quarantines, restrictions on travel and movements, factory closures, and supply chain disruptions. This will lead to mismatch of supply and demand therefore, it is very essential from an economic policy point of view to find out the initial consequences and how to deal witha decline in many business activities through monetary, financial and fiscal or any feasible tools. Therefore, the concerned body should do whatever it takes and to use all available options by forecasting or identifying whether the situation is stopped in the short run or continue to affect the economy. Therefore, study recommends the government to immediately restructure the political thinking of the respondents and take corrective measures so as to reduce the political instability of the zones and create detail awareness about Covid 19 in order to minimize the human cost of the pandemic and the political instability. The higher officials are expected to work so as to minimize the regressive effects of the business and political crisis, with measures to protect communities ' incomes, especially low-income ones; and, the country in general. In addition, it is advisable to preserve macroeconomic stability and the capacity to resume growth once the economic crisis resulting from the pandemic concludes.

It is always difficult for governments to rapidly readjust their plans, especially when this implies a radical shift. Every government has legitimate objectives associated with infrastructure projects, education, rural and regional development programs, and any activities conducted in the country and the like. Therefore the government has to rethink how to overcome this pandemic situation if the situation continues or not. Because both situation may requires different measures.

The zone managers must balance between the need to keep the business transactions going and the need to protect the populations from this current pandemic. Hence, the zone officials or any concerned body should review their activities towards protecting the Covid 19 pandemic to create a promisingatmosphere to continue flows of essential transactions.

In the longer term, each official andthe individualsjointly may need to look at ways to further strengthen their economic protection for better readiness for future crises.

If the Covid-19 will continue to occur, but where and how severe the next pandemic will be, no one can predict. The concerned office has to work to minimize any long term consequence on productivity by enhancing preparedness to rebuild the economy in the aftermath of the pandemic.

Thus, the East Wollega officials has to strive in accordance with in the fight against current and future pandemics, national and regional efforts need to be complemented by and strengthened with international cooperation.

\section{References}

A. Edgecliffe-Johnson, March 2020 "Coronavirus lay-offs split corporate America”, Financial Times, New York, https://www.ft.com.

Abdul Abiad; March; 2020, The Economic Impact of the COVID-19 Outbreak on Developing Asia; ADB BRIEFS, NO. 128.

ASEAN Policy Brief; April 2020, Economic Impact of COVID-19 Outbreak on ASEAN

Africa Union, 2020, Impact of the Coronavirus (Covid 19) On the African Economy

Deloitte, May 2020, Economic Impact of the COVID-19 Pandemic on East African Economies: Summary of government intervention measures and Deloitte insights.

FAO of the UN, April 2020, Addressing the impacts of COVID-19 in food crises, April-December 2020; FAO's component of the Global COVID-19 Humanitarian Response Plan, www.fao.org,

Hasan El-Mousawi\&Hasan Kanso,2020, Impact of COVID-19 Outbreak on Financial Reporting in the Light of the International Financial Reporting Standards (IFRS) (An Empirical Study), Research in Economics and Management ;Vol. 5, No. 2, 2020

ISM 2020, “COVID-19 Survey: Impacts on Global Supply Chains", Institute for Supply Management: https: //www.instituteforsupplymanagement.org. Item Number=31171

JyotiKoirala and SumanAcharya 2020; Economic Impact of COVID-19 in Nepal: A Question of Bad or Worst; Electronic copy available at: https://ssrn.com. 
Marco T. and Matteo M. W; 2020; Coronavirus-Infected International Business Transactions: A Preliminary Diagnosis; European Journal of Risk Regulation Vol. 00:00

Maya Misikir; 17 APRIL 2020 Addis Fortune; Addis Ababa; Ethiopia.

OECD; 2020 Evaluating the initial impact of COVID-19 containment measures on economic activity, OECD, Paris. pp. 2-3.

Responsible Business Alliance; 2020, "COVID-19 Impact at a Glance", in RBA Brief, http://www.responsiblebusiness.org/.pdf, p.1.

Sourcemap, 2020) "How the coronavirus is affecting consumer supply chains", :https://www.sourcemap.com.

- World Bank, 2019 - Draft Analysis - COVID-19: Potential Poverty and Social Impacts in Ethiopia and Policy Responses. This note was prepared by the Ethiopia team of the Poverty and Equity Global Practice. 